\title{
Sustainable accounting reporting practices of Indian cement industry: An exploratory study
}

\author{
Shagufta Khan ${ }^{a}$, Vineet Chouhan ${ }^{b^{*}}$, Bibhas Chandra ${ }^{c}$ and Shubham Goswami ${ }^{\text {b }}$
}

${ }^{a}$ Research Scholar, School of Management, Sir Padampat Singhania University, Udaipur-India

${ }^{b}$ Assistant Professor, School of Management, Sir Padampat Singhania University, Bhatewar, Udaipur-India, 313601

${ }^{c}$ Associate Professor, School of Management, Sir Padampat Singhania University, Bhatewar, Udaipur-India, 313601

\section{H R O N I C L E}

Article history:

Received September 10, 2013

Received in revised format

10 December 2013

Accepted February 252014

Available online

February 272014

Keywords:

Cement Industry

Sustainability

Financial Information

Environment

Accounting Reporting

Sustainable Reporting Practices

\section{A B S T R A C T}

Cement is the single most important and profitable product in the building material sector. With the economic boom, in India, Indian cement industry is a market of opportunities waiting to be tapped. However, at the same time cement industry is also experiencing a surge in demand. Production of Cement will always release carbon dioxide and change in the climate of the earth that is why despite its profitability, the cement industry faces many challenges regarding environmental concerns and sustainability issues. In order to minimize the impact of all of the above mentioned issues, it is clear that the cement and construction industry will have to adapt to remain sustainable and in this process a number of innovative and new practices have to be adopted. The objective of this paper is to analyze the gap between the existing reporting practices and level of disclosure desired by stakeholders of cement companies and to identify the areas under which Indian Cement companies can report accounting information in sustainable way. Furthermore it is also required to align the reporting is as per stakeholder's requirement. The accounting areas of reporting will be explored so that the requirements of reporting in terms of financial character can be filled in. This may lead to change in the practices under which the current financial statement provides financial information of sustainable activity as non-financial activity and its cost has been shown in the miscellaneous expenditure.

\section{Introduction}

Environmental degradation is a burning issue that requires the attention of the whole world, specifically, when the effect of global warming has reached its height and has taken a shape of a monster that is going to gobble the earth very soon. However, the consequences of environmental disaster have resulted some alertness in peoples mind. Living in a world of limited resources business must concern itself with issues such as environmental damage, the treatment of workers, and product safety (Ho et al., 2007). In the past decade, issues related to climate change are gathering enormous public attention, while the governments nationally and internationally have lagged behind in

* Corresponding author. Tel.: +91-9772778431

E-mail addresses: vineet.chouhan@spsu.ac.in (V. Chouhan)

C) 2014 Growing Science Ltd. All rights reserved. doi: $10.5267 / j$.uscm.2014.2.001 
developing a policy framework to address these issues at the face values. The role of India pertaining to the related issues is increasingly significant. The forthcoming challenges are global and thus, must be dealt with alacrity. The most acclaimed and widely agreeable way to address climate change is to adopt sustainable path of development, which can be gained by environmentally sustainable technologies; promoting renewal energy and encouraging the business community to demonstrate some sense towards environment accountability. A host of sustainable activities, so far, has been carried out at the different levels viz. government, NGOs', and international forum (like UNCED, 1992 at Rio de Janerio; UNFCCC and Kyoto Protocol etc.) but results are not fructifying to the desired extent "(Perry, 2000).

As all the stakeholders i.e., investors, insurers, bankers and others are increasingly aware of business ethics, environmental liabilities and risks. Thus, environmental reporting(ER) is at the heart of this agenda (Perry, 2000). GRI has added to the value of ER practices by remarking that sustainability reporting helps sharpen management ability to access the organization's contribution to natural, human, and social capital. Reporting helps highlight the societal and ecological contribution of the organization and "sustainability value proposition" of its products and services. ER is essential for corporation as it serve as an indicator for corporate consciousness through a moral disclosure on environmental issues (Suminai et al., 2007; Brown \& Deegan, 1998). It also gives companies the opportunity to gain many benefits (KPMG Stockholm, 1997).

KPMG international survey ER (1999) shows that out of 13 major countries surveyed, ER has become part of the annual reporting process (KPMG, 1999). It may appear that greater attention to environment issues may led to an increase in cost and hence lower profit, but in real world environmental reporting practices have real advantages (Fortes, 2002). The disclosure of environmental information attracts attention as the information itself involves the living quality despite the fact that such reporting is voluntary in nature (Ahmad et al, 2003). In the current scenario stakeholders require that companies should provide its sustainable information in financial terms not in the form of non-financial Information (Lorenz et al., 2007; Sharma et al., 2003; Hira, 2012 ), Thus, as per the stakeholders requirement the current study explore the environmental, social and economic dimensions, in which the requirement of stakeholders can be met.

The main objectives of the current study are enlisted as below:

1. To identify the prominent sustainability factors on environmental, social and economic dimension from review of related literature,

2. To identify the reporting pattern of sustainability factors for select cement companies in India,

3. To analyze the gap between the existing reporting practices and level of disclosure desired by stakeholders of cement companies.

\section{Indian cement industry}

Cement is the single most important and profitable product in the building material. With an 8\% GDP growth rate, governmental infrastructure augmentation and population expansion, the Indian cement industry is a market of opportunities waiting to be tapped. India has become the second largest producer of Cement in the world after China. As per a survey sector, the consumption of cement in India will be increased by 600 million tonnes by the year 2020 (Shankar et al., 2011) and with the economic boom in India, the cement industry is experiencing a surge in demand. It is a wellestablished and widely believed in society that greenhouse gases are the major contributor behind the changes in the climate of the planet. It is equally well established from many scientific investigations that one of the prime culprits is carbon dioxide, and recent years have seen increasing legislation to 
try and limit carbon dioxide emissions. Protesters often confront car makers, oil companies, power companies, shipping firms and the airline industry for their contribution to emissions, but one lowprofile business which contributes a sizeable portion of 5-6\% to greenhouse gas emissions. This Industry has so far escaped attention of strategy makers (Adam, 2007; Rodrigues et al., 2010). Furthermore, cement production will always release carbon dioxide, because one cannot change the chemistry of the process.

Despite its popularity and profitability, the cement industry faces many challenges due to environmental concerns and sustainability issues. It is fundamentally an energy intensive operation and not at all environmentally friendly by nature. Furthermore, it consumes large amounts of nonrenewable raw materials and generates substantial amounts of carbon dioxide and environmental particulate matter in the process.

In order to minimize the impact of all of the above mentioned issues, it is clear that the cement and construction industry will have to adapt to remain sustainable and in the process adopt a number of innovative and new practices. It should be fairly obvious that a holistic approach is being called for to ensure survival an prosperity for the cement industry in future. The cement companies over the period have been recognizing their sustainable practices but there is meager commitment to disclose the financial information related to these activities. Only a few concerns have separately recognized this amount in the Profit and Loss account as green belt development or horticulture expenses. Many few companies have reported "any significant accounting or reporting policies' or 'extraordinary items' in the annual report. This shows that in India, quantitative /financial reporting on Environmental issues is still at the infancy stage. It has been seen from the annual reports that most polluting companies disclose more environmental information than the entities in the less polluting industries.

The common practice followed by the companies regarding environment disclosure is to offer descriptive information in the annual reports. This trend is increasing over time. Nevertheless, the companies that disclose financial information on environmental issues do not include do not provide any item-time wise break up of expenditure or its accounting treatment in these reports. However, some companies have given elaborate information through charts and tables on pollution levels or emission of pollutants. The majority of companies disclose only qualitative/descriptive information on the environment in the annual report. Though a few companies have started reporting quantitative /financial figures on the issue, the information provided is generally brief and lacks specific details. Moreover, there is no consistency in this kind of reporting (Andreson \& Skjott-Larsen, 2009).

\section{Literature review}

The issue of environmental disclosure has received the attention of researchers and academicians from many different points of view. One strand of literature deals with the nature and extent of environmental disclosure, while the other strand captures the impact of environmental information on the various users and the market. There is however, another section of researchers who have started to extent the empirical environmental disclosure literature by focusing on a number of firm specific characteristics, which are potential determinants of environmental reporting practices. The present study attempts to explore the area in which there is a requirement to provide sustainable accounting reporting. The current section will provide selective review of literature in context to only determinants of sustainable accounting reporting /disclosure factors. The reviews of literature in this section are presented through Table 1. 
Table 1(a)

Review of literature of sustainable factors: environmental factors

\begin{tabular}{|c|c|c|c|c|}
\hline Author & Factors & Country & $\begin{array}{l}\text { Sample size and } \\
\text { Industry }\end{array}$ & Results \\
\hline $\begin{array}{l}\text { Wiseman, } \\
1982\end{array}$ & $\begin{array}{l}\text { Environmental disclosures } \\
\text { made in corporate annual } \\
\text { reports }\end{array}$ & US & $\begin{array}{l}26 \text { firms in } \\
\text { environmentally } \\
\text { sensitive } \\
\text { industries }\end{array}$ & $\begin{array}{l}\text { Corporate Environmental Disclosures are incomplete } \\
\text { and are not related to the firms' actual environmental } \\
\text { performance. }\end{array}$ \\
\hline $\begin{array}{l}\text { Adhikari \& } \\
\text { Tondkar, } 1992\end{array}$ & Environmental factors & $\begin{array}{l}\text { Global } \\
\text { Stock } \\
\text { Exchanges. }\end{array}$ & $\begin{array}{l}35 \text { Stock } \\
\text { Exchanges in } \\
\text { different } \\
\text { countries }\end{array}$ & $\begin{array}{l}\text { Size of the equity market is found to be a significant } \\
\text { explanatory variable. }\end{array}$ \\
\hline $\begin{array}{l}\text { Al-Tuwaijria } \\
\text { et al., } 2004\end{array}$ & $\begin{array}{l}\text { Environmental disclosure, } \\
\text { environmental } \\
\text { performance, economic } \\
\text { performance }\end{array}$ & $\begin{array}{l}\text { Florida, } \\
\text { California }\end{array}$ & $\begin{array}{l}\text { Alcoa company } \\
1992-94\end{array}$ & $\begin{array}{l}\text { Environmental Performance is significantly } \\
\text { associated with "good" economic performance, and } \\
\text { also with more extensive quantifiable environmental } \\
\text { disclosures of specific pollution measures and } \\
\text { occurrences }\end{array}$ \\
\hline $\begin{array}{l}\text { Bowman \& } \\
\text { Haire, } 1975\end{array}$ & $\begin{array}{l}\text { Profitability and corporate } \\
\text { social responsibility } \\
\text { disclosure }\end{array}$ & US & $\begin{array}{l}\text { food processing } \\
\text { business } \\
\text { companies }\end{array}$ & $\begin{array}{l}\text { Relationship between corporate profitability and } \\
\text { corporate social responsibility disclosures in food } \\
\text { processing business companies in US }\end{array}$ \\
\hline $\begin{array}{l}\text { Cowen et al., } \\
1987\end{array}$ & $\begin{array}{l}\text { Corporate characteristics } \\
\text { and specific types of } \\
\text { social responsibility } \\
\text { disclosures }\end{array}$ & US & $\begin{array}{l}\text { US corporate } \\
\text { annual reports }\end{array}$ & $\begin{array}{l}\text { Found that corporate size and industry category } \\
\text { correlates with certain types of disclosures while the } \\
\text { existence of a corporate social responsibility } \\
\text { committee appears to correlate with one particular } \\
\text { type of disclosure }\end{array}$ \\
\hline $\begin{array}{l}\text { Hackston \& } \\
\text { Milne, } 1996\end{array}$ & $\begin{array}{l}\text { Description of corporate } \\
\text { social disclosure practices }\end{array}$ & $\begin{array}{l}\text { New } \\
\text { Zealand }\end{array}$ & $\begin{array}{l}\text { New Zealand } \\
\text { companies }\end{array}$ & $\begin{array}{l}\text { Found that size disclosure relationship is much } \\
\text { stronger for the high profile industry companies than } \\
\text { for the low profile industry companies. }\end{array}$ \\
\hline $\begin{array}{l}\text { Adams et al., } \\
1998\end{array}$ & $\begin{array}{l}\text { Corporate social reporting } \\
\text { practices }\end{array}$ & $\begin{array}{l}\text { European } \\
\text { countries }\end{array}$ & $\begin{array}{l}\text { a sample of } 150 \\
\text { annual reports } \\
\text { from six } \\
\text { European } \\
\text { countries }\end{array}$ & $\begin{array}{l}\text { The findings of the study indicate that the amount } \\
\text { and nature of social disclosure varied significantly } \\
\text { across countries } \\
\text { However, the overall result show that the firm size } \\
\text { and industry membership are important determinants } \\
\text { of the level of social disclosures in all the six } \\
\text { European countries }\end{array}$ \\
\hline Reverte (2009) & $\begin{array}{l}\text { firm characteristics and } \\
\text { environmental disclosure }\end{array}$ & $\begin{array}{l}\text { Spanish } \\
\text { listed firms }\end{array}$ & $\begin{array}{l}\text { Spanish listed } \\
\text { firms }\end{array}$ & $\begin{array}{l}\text { The findings of the study revealed that firms with } \\
\text { higher corporate social responsibility disclosure } \\
\text { (CSR) rating has statistically significant larger size } \\
\text { and a higher media exposure and belong to more } \\
\text { environmentally sensitive industries, as compared to } \\
\text { firms with lower CSR ratings }\end{array}$ \\
\hline $\begin{array}{l}\text { Maria et al., } \\
2010\end{array}$ & $\begin{array}{l}\text { Extent of environmental } \\
\text { disclosure practices }\end{array}$ & Portugal & 109 Large firms & $\begin{array}{l}\text { They found that the firm size and the fact that a } \\
\text { company is listed on the stock market are positively } \\
\text { related to the extent of environmental disclosure }\end{array}$ \\
\hline $\begin{array}{l}\text { Gamble et al., } \\
1995\end{array}$ & $\begin{array}{l}\text { the quality of } \\
\text { environmental disclosures }\end{array}$ & $\begin{array}{l}\text { Fortune } \\
500 \\
\text { companies }\end{array}$ & $\begin{array}{l}\text { Annual reports } \\
\text { of } 234 \\
\text { companies, } 12 \\
\text { industries, } 1986 \\
\text { and } 1991 .\end{array}$ & $\begin{array}{l}\text { An instrument was designed to measure the content } \\
\text { of environmental disclosures, and descriptive } \\
\text { reporting codes were used, based on the manner in } \\
\text { which the sample firms disclosed environmental } \\
\text { information in Cement Companies. }\end{array}$ \\
\hline $\begin{array}{l}\text { Fekrat et al., } \\
1996\end{array}$ & $\begin{array}{l}\text { the scope and accuracy of } \\
\text { environmental disclosures } \\
\text { made in corporate annual } \\
\text { reports }\end{array}$ & US & $\begin{array}{l}\text { Environmental } \\
\text { disclosures of } \\
168 \text { companies } \\
\text { in six industries } \\
\text { from } 18 \\
\text { countries }\end{array}$ & $\begin{array}{l}\text { The result indicated significant variations in } \\
\text { environmental disclosures, and no clear support for } \\
\text { the voluntary disclosure hypothesis, as well as a lack } \\
\text { of association between disclosures and } \\
\text { environmental performances. }\end{array}$ \\
\hline $\begin{array}{l}\text { Walden \& } \\
\text { Schwartz, } \\
1997\end{array}$ & $\begin{array}{l}\text { quantity and quality of } \\
\text { information related with } \\
\text { Environmental disclosures }\end{array}$ & $\begin{array}{l}1989 \text { Exxon } \\
\text { Valdez oil } \\
\text { spill, off } \\
\text { Alaska }\end{array}$ & $\begin{array}{l}53 \text { companies in } \\
\text { four industries } \\
\text { for } 1988-90\end{array}$ & $\begin{array}{l}\text { The authors interpret the results as showing that } \\
\text { environmental disclosures in these industries were } \\
\text { time or event specific, and made in the self-interest } \\
\text { of the firm. }\end{array}$ \\
\hline $\begin{array}{l}\text { Lawrence \& } \\
\text { Khurana, } 1997\end{array}$ & $\begin{array}{l}\text { the financial reporting and } \\
\text { public policy issues }\end{array}$ & $\begin{array}{l}\text { US } \\
\text { municipal } \\
\text { landfills }\end{array}$ & Municipalities & $\begin{array}{l}\text { The extent of municipal landfill cleanup costs is } \\
\text { revealing since the earliest site was dated at } 1880 \text {, } \\
\text { and a great many dated from the ' } 930 \text { s. This aspect } \\
\text { along suggests that in some cases the extent of } \\
\text { environmental cleanup extends further in both extent } \\
\text { (public sector as well as private sector } \\
\text { responsibilities) and time period. }\end{array}$ \\
\hline
\end{tabular}


Table 1(b)

Review of literature of sustainable factors; economic disclosure

\begin{tabular}{|c|c|c|c|c|}
\hline Author & Factors & Country & $\begin{array}{l}\text { Sample size } \\
\text { and Industry }\end{array}$ & Results \\
\hline Idowu, 2011 & $\begin{array}{l}\text { Accounting for } \\
\text { Decision Makers } \\
\text { in a Sustainable } \\
\text { Environment }\end{array}$ & London & $\begin{array}{l}\text { Not } \\
\text { mentioned }\end{array}$ & $\begin{array}{l}\text { Accounting under Sustainable } \\
\text { Environment is an important factor for } \\
\text { Decision Makers. }\end{array}$ \\
\hline $\begin{array}{l}\text { Fernandez- } \\
\text { Feijoo et al., } \\
2013\end{array}$ & $\begin{array}{l}\text { Transparency of } \\
\text { the sustainability } \\
\text { reports }\end{array}$ & $\begin{array}{l}\text { Spain and } \\
\text { USA }\end{array}$ & $\begin{array}{l}\text { Not } \\
\text { mentioned }\end{array}$ & $\begin{array}{l}\text { Transparency is affected by ownership, } \\
\text { along with size and global region }\end{array}$ \\
\hline $\begin{array}{l}\text { Perego \& } \\
\text { Kolk, } 2012\end{array}$ & $\begin{array}{l}\text { shape the quality } \\
\text { of sustainability } \\
\text { assurance }\end{array}$ & $\begin{array}{l}\text { Various } \\
\text { countries }\end{array}$ & $\begin{array}{l}\text { Fortune } \\
\text { Global } 250 \\
\text { firms, Period } \\
10 \text { years }\end{array}$ & $\begin{array}{l}\text { Need to enhance theory-based, cross- } \\
\text { disciplinary knowledge related to auditing } \\
\text { and accountability processes for } \\
\text { sustainability }\end{array}$ \\
\hline $\begin{array}{l}\text { Michelon \& } \\
\text { Parbonetti, } \\
2012\end{array}$ & $\begin{array}{l}\text { board } \\
\text { composition, } \\
\text { leadership and } \\
\text { structure on } \\
\text { sustainability } \\
\text { disclosure }\end{array}$ & $\begin{array}{l}\text { US and } \\
\text { European } \\
\text { companies }\end{array}$ & $\begin{array}{l}100 \\
\text { companies } \\
\text { of various } \\
\text { industries }\end{array}$ & $\begin{array}{l}\text { board composition effect sustainability } \\
\text { disclosure, }\end{array}$ \\
\hline $\begin{array}{l}\text { Lülfs \& Hahn, } \\
2013\end{array}$ & $\begin{array}{l}\text { GRI, Corporate } \\
\text { Governance }\end{array}$ & $\begin{array}{l}\text { German } \\
\text { companies }\end{array}$ & $\begin{array}{l}\text { Various } \\
\text { industries }\end{array}$ & $\begin{array}{l}\text { It aims to improve the overall "balance" of } \\
\text { sustainability true and fair view in } \\
\text { sustainability disclosure required }\end{array}$ \\
\hline $\begin{array}{l}\text { Samaha et al., } \\
2012\end{array}$ & $\begin{array}{l}\text { Corporate } \\
\text { Governance }\end{array}$ & Egypt & $\begin{array}{l}\text { active share } \\
\text { trading firms } \\
\text { in Egypt. }\end{array}$ & $\begin{array}{l}\text { corporate governance code has not } \\
\text { improved information symmetry as the } \\
\text { overall level of Disclosure. }\end{array}$ \\
\hline $\begin{array}{l}\text { Steurer et al. } \\
2005\end{array}$ & $\begin{array}{l}\text { Stakeholder } \\
\text { relations, } \\
\text { economic, social, } \\
\text { and environmental } \\
\text { stakeholder }\end{array}$ & $\begin{array}{l}\text { Austrian } \\
\text { companies }\end{array}$ & $\begin{array}{l}\text { Various } \\
\text { industries }\end{array}$ & Significance of societal guiding models \\
\hline Mook, 2006 & $\begin{array}{l}\text { Economic, Social } \\
\text { and } \\
\text { Environmental } \\
\text { Performance }\end{array}$ & Canada & $\begin{array}{l}\text { Various } \\
\text { industries }\end{array}$ & $\begin{array}{l}\text { Social environmental values added } \\
\text { statement }\end{array}$ \\
\hline Mäler, 1999 & $\begin{array}{l}\text { Resource } \\
\text { Accounting, } \\
\text { Sustainable } \\
\text { Development }\end{array}$ & Netherlands & $\begin{array}{l}\text { Various } \\
\text { industries }\end{array}$ & $\begin{array}{l}\text { environmental resources were cheerfully } \\
\text { ignored }\end{array}$ \\
\hline $\begin{array}{l}\text { Simnett et al., } \\
2009\end{array}$ & $\begin{array}{l}\text { Assurance of } \\
\text { financial } \\
\text { performance }\end{array}$ & $\begin{array}{l}31 \\
\text { countries }\end{array}$ & $\begin{array}{l}2,113 \\
\text { companies }\end{array}$ & $\begin{array}{l}\text { Companies operating in stakeholder- } \\
\text { orientated countries are more likely to } \\
\text { choose the sustainable practices as an } \\
\text { assurer. }\end{array}$ \\
\hline $\begin{array}{l}\text { Cohen et al., } \\
2012\end{array}$ & $\begin{array}{l}\text { economic } \\
\text { performance }\end{array}$ & UK & $\begin{array}{l}2004 \text { by a } \\
\text { sample of } 50 \\
\text { publicly } \\
\text { traded firms } \\
\text { across five } \\
\text { industries }\end{array}$ & $\begin{array}{l}\text { The findings of this paper revealed types } \\
\text { of sustainable accounting disclosures } \\
\text { would benefit the company }\end{array}$ \\
\hline
\end{tabular}


Table 1(c)

Review of literature of sustainable factors; social factors

\begin{tabular}{|c|c|c|c|c|}
\hline Author & Factors & Country & $\begin{array}{l}\text { Sample size and } \\
\text { Industry }\end{array}$ & Results \\
\hline $\begin{array}{l}\text { Leigh \& Williams, } \\
1998\end{array}$ & $\begin{array}{l}\text { Voluntary } \\
\text { environment and } \\
\text { social accounting } \\
\text { disclosure practices }\end{array}$ & $\begin{array}{l}\text { Asia pacific } \\
\text { country }\end{array}$ & $\begin{array}{l}\text { Listed companies' } \\
\text { of seven countries } \\
\text { in Asia-Pacific } \\
\text { region }\end{array}$ & $\begin{array}{l}\text { This study provides insight into the understanding of variables } \\
\text { that explain variations in voluntary environmental and social } \\
\text { accounting disclosures across national and regional boundaries. }\end{array}$ \\
\hline Ali \& Rizwan, 2013 & $\begin{array}{l}\text { Corporate } \\
\text { Environment and } \\
\text { social accounting } \\
\text { disclosure practices in } \\
\text { developing countries }\end{array}$ & $\begin{array}{l}\text { Developing } \\
\text { Countries }\end{array}$ & $\begin{array}{l}\text { An Institutional } \\
\text { theoretical } \\
\text { perspective of } \\
\text { CSED in } \\
\text { developing } \\
\text { countries }\end{array}$ & $\begin{array}{l}\text { This study contributes to the literature on Corporate Social and } \\
\text { Environmental Disclosure (CSED hereafter) in the developing } \\
\text { countries by exploring various influential factors for CSED and } \\
\text { grouping them into three categories: normative, interest, and } \\
\text { company groups }\end{array}$ \\
\hline $\begin{array}{l}\text { Kuasirikun \& Sherer, } \\
2004\end{array}$ & $\begin{array}{l}\text { Corporate social } \\
\text { accounting disclosure }\end{array}$ & Thailand & Thai companies & $\begin{array}{l}\text { It concern is to gain insights into and to critically appraise } \\
\text { various dimensions of these annual reports, so as to construct a } \\
\text { critique of corporate social disclosure in Thailand. }\end{array}$ \\
\hline Orij, 2007 & $\begin{array}{l}\text { Corporate Social } \\
\text { Disclosures and } \\
\text { Accounting Theories }\end{array}$ & $\begin{array}{l}500 \\
\text { companies } \\
\text { of } 22 \\
\text { Countries }\end{array}$ & $\begin{array}{l}13 \text { scoring items, } \\
186 \text { CSR items }\end{array}$ & $\begin{array}{l}\text { This study reviews the use of accounting theory in explaining } \\
\text { corporate social disclosure Behaviour. The combination of } \\
\text { social disclosures behaviour and voluntary accounting } \\
\text { disclosures turns out to be a promising new field of Research. }\end{array}$ \\
\hline Gray et al., 1995 & $\begin{array}{l}\text { categorisation of } \\
\text { corporate } \\
\text { social and } \\
\text { environmental } \\
\text { disclosure studies }\end{array}$ & $\begin{array}{l}\text { U. K. } \\
\text { Companies, } \\
13 \text { year } \\
\text { data. }\end{array}$ & $\begin{array}{l}\text { Decision } \\
\text { Usefulness } \\
\text { Studies, } \\
\text { Economic Theory } \\
\text { Studies, Social } \\
\text { and political }\end{array}$ & $\begin{array}{l}\text { Explain decision-usefulness studies by describing some studies } \\
\text { and their results. The decision usefulness generally relates to } \\
\text { the usefulness of accounting } \\
\text { information, which is social accounting information in this case }\end{array}$ \\
\hline Milne, 2010 & $\begin{array}{l}\text { Positive accounting } \\
\text { theory, political costs } \\
\text { And social disclosure } \\
\text { analyses: a critical } \\
\text { look }\end{array}$ & US & $\begin{array}{l}\text { large US oil } \\
\text { companies }\end{array}$ & $\begin{array}{l}\text { The positive accounting based social disclosures literature fails } \\
\text { to provide distinct arguments for self-interested managers } \\
\text { wealth maximising. This paper also shows that the empirical } \\
\text { evidence gathered to date in support of a positive accounting } \\
\text { theory of social disclosures largely fails in its endeavour. }\end{array}$ \\
\hline van der Laan, 2009 & $\begin{array}{l}\text { Corporate Social } \\
\text { Disclosures: } \\
\text { Voluntary } \\
\text { Disclosures vs } \\
\text { 'Solicited' } \\
\text { Disclosures }\end{array}$ & Australia & $\begin{array}{l}\text { Non-government } \\
\text { organizations } \\
\text { (NGOs) }\end{array}$ & $\begin{array}{l}\text { Theoretical perspectives may provide greater insights into } \\
\text { managerial motivation for disclosure if they are linked more } \\
\text { explicitly to the nature of corporate social disclosure under } \\
\text { examination: voluntary or solicited. }\end{array}$ \\
\hline $\begin{array}{l}\text { Guthrie \& Parker, } \\
1990\end{array}$ & $\begin{array}{l}\text { Corporate social } \\
\text { disclosure types and } \\
\text { practices }\end{array}$ & $\begin{array}{l}\text { UK, US } \\
\text { and } \\
\text { Australia }\end{array}$ & $\begin{array}{l}\text { UK, US and } \\
\text { Australia }\end{array}$ & $\begin{array}{l}\text { This study makes use of } 15 \text { content categories divided into four } \\
\text { main classificatory groupings which aim to analyze the } \\
\text { material contained in corporate annual reports in terms of } \\
\text { theme, evidence/method, amount and location of disclosure }\end{array}$ \\
\hline $\begin{array}{l}\text { Lydenberg \& Grace, } \\
2008\end{array}$ & $\begin{array}{l}\text { Innovations in } \\
\text { Social and } \\
\text { Environmental } \\
\text { Disclosure } \\
\text { Outside the United } \\
\text { States } \\
\end{array}$ & $\begin{array}{l}\text { Brazil, } \\
\text { France, } \\
\text { Malaysia, } \\
\text { South } \\
\text { Africa, } \\
\text { Sweden } \\
\end{array}$ & 116 companies & $\begin{array}{l}\text { This paper highlights various noteworthy developments } \\
\text { worldwide on environmental and social reporting requirements } \\
\text { by regulatory bodies } \\
\text { and stock exchanges. }\end{array}$ \\
\hline
\end{tabular}

\section{Sustainability reporting factors}

For the purpose of current research, initially a sample of 10 cement companies will be taken to identify the sustainable accounting practices and to check out the areas in which companies are reporting sustainable accounting. With this, an emphasis will also be given to know the area which will be utilized under the proposed research study. As the research progresses a large sample of cement companies will be taken to ensure a broad research analysis. The table 1 shows area covered under various factors of sustainability development.

Table 1

Areas Covered under Various Factors relating to sustainability

\begin{tabular}{lll}
\hline Environmental Factors & Social Factors & Economic Factors \\
\hline$\bullet$ Energy & $\bullet$ Community investment & $\bullet$ Accountability/Transparency \\
$\bullet$ Water & $\bullet$ working condition & $\bullet$ Corporate Governance \\
- Greenhouse Gases Emission & $\bullet$ Human rights and fair trade & $\bullet$ Stakeholder Value \\
$\bullet$ Hazardous and non-hazardous waste & $\bullet$ Public Policy & $\bullet$ Economic performance \\
- Recycling & $\bullet$ Diversity & $\bullet$ Fuels and Material \\
- Agro based Livelihood & $\bullet$ Safety & $\bullet$ Training \\
- Mine development & $\bullet$ Education & $\bullet$ Financial Performance \\
$\bullet$ Waste Heat Recovery & $\bullet$ Health and family welfare \\
- Concrete Recycling & $\bullet$ Anticorruption & \\
$\bullet$ Packaging & $\bullet$ Woman Empowerment & \\
\hline
\end{tabular}


On the basis of the 28 variables selected from the review of literature related with sustainable accounting reporting practices, 10 cement companies were selected as a representative sample among cement companies in India. The annual reports and sustainability report of various sample companies were analyzed to identify their sustainability reporting. For this purpose, the information received is divided into 3 parts i.e., non-disclosed (3), non-Financial disclosure (2) and financial disclosure (3). The best way of reporting this sustainable information is to report for all the above items financially (3). As per the objectives of this paper, first it is analyzed that whether there is a difference between the sample companies in terms of accounting reporting. For this purpose, one sample $\mathrm{T}$ test is being used for the data collected from the sample cement companies. The descriptive of the data are shown in Table 2.

\section{Table 2}

Descriptive Statistics of current sustainable reporting practices of Indian Cement Companies

\begin{tabular}{|c|c|c|c|c|c|c|c|c|}
\hline & \multirow{2}{*}{$\frac{\mathrm{N}}{\text { Statistic }}$} & \multirow{2}{*}{$\begin{array}{c}\text { Range } \\
\text { Statistic }\end{array}$} & \multirow{2}{*}{$\begin{array}{l}\text { Minimum } \\
\text { Statistic }\end{array}$} & \multirow{2}{*}{$\begin{array}{l}\text { Maximum } \\
\text { Statistic }\end{array}$} & \multicolumn{2}{|c|}{ Mean } & \multirow{2}{*}{$\begin{array}{c}\text { Std. Deviation } \\
\text { Statistic }\end{array}$} & \multirow{2}{*}{$\begin{array}{l}\text { Variance } \\
\text { Statistic }\end{array}$} \\
\hline & & & & & Statistic & Std. Error & & \\
\hline ACC & 28 & 2.00 & 1.00 & 3.00 & 2.2500 & .14203 & .75154 & .565 \\
\hline AMBUJA & 28 & 2.00 & 1.00 & 3.00 & 2.7143 & .10102 & .53452 & 286 \\
\hline BINANI & 28 & 2.00 & 1.00 & 3.00 & 2.0357 & .14069 & .74447 & .554 \\
\hline $\mathrm{JK}$ & 28 & 2.00 & 1.00 & 3.00 & 2.2500 & .13239 & .70053 & .491 \\
\hline SHREE & 28 & 2.00 & 1.00 & 3.00 & 2.8214 & .08988 & .47559 & .226 \\
\hline ULTRATECH & 28 & 2.00 & 1.00 & 3.00 & 2.6071 & .13934 & .73733 & .544 \\
\hline RAIN & 28 & 2.00 & 1.00 & 3.00 & 2.1071 & .10714 & .56695 & .321 \\
\hline PRISM & 28 & 2.00 & 1.00 & 3.00 & 1.9643 & .14980 & .79266 & .628 \\
\hline MADRAS & 28 & 2.00 & 1.00 & 3.00 & 2.1071 & .18068 & .95604 & .914 \\
\hline INDIA & 28 & 2.00 & 1.00 & 3.00 & 2.0000 & .14548 & .76980 & .593 \\
\hline Valid N (listwise) & 28 & & & & & & & \\
\hline
\end{tabular}

Table 2 shows that there is a significant difference between the reporting patterns of sustainability, as the standard deviation of the reporting varies between 0.4 to 0.9 . The results of t test were shown in Table 3.

\section{Table 3}

One-Sample T Test

\begin{tabular}{|c|c|c|c|c|c|c|}
\hline & \multicolumn{6}{|c|}{ Test Value $=3$} \\
\hline & \multirow[b]{2}{*}{$\mathrm{t}$} & \multirow[b]{2}{*}{$\mathrm{df}$} & \multirow[b]{2}{*}{ Sig. (2-tailed) } & \multirow[b]{2}{*}{ Mean Difference } & \multicolumn{2}{|c|}{$\begin{array}{l}\text { 95\% Confidence Interval of the } \\
\text { Difference }\end{array}$} \\
\hline & & & & & Lower & Upper \\
\hline $\mathrm{ACC}$ & -5.281 & 27 & .000 & -.75000 & -1.0414 & -.4586 \\
\hline AMBUJA & -2.828 & 27 & .009 & -.28571 & -.4930 & -.0784 \\
\hline BINANI & -6.854 & 27 & .000 & -.96429 & -1.2530 & -.6756 \\
\hline $\mathrm{JK}$ & -5.665 & 27 & .000 & -.75000 & -1.0216 & -.4784 \\
\hline SHREE & -1.987 & 27 & .057 & -.17857 & -.3630 & .0058 \\
\hline ULTRATECH & -2.819 & 27 & .009 & -.39286 & -.6788 & -.1070 \\
\hline RAIN & -8.333 & 27 & .000 & -.89286 & -1.1127 & -.6730 \\
\hline PRISM & -6.914 & 27 & .000 & -1.03571 & -1.3431 & -.7284 \\
\hline MADRAS & -4.942 & 27 & .000 & -.89286 & -1.2636 & -.5221 \\
\hline INDIA & -6.874 & 27 & .000 & -1.00000 & -1.2985 & -.7015 \\
\hline
\end{tabular}

One sample Test of various cement companies shows that in only one company a similar pattern of reporting is adopted $(\mathrm{t}=-1.987$ and $\mathrm{p}=0.057>0.05)$, while on rest of the companies the difference in reporting of sustainable accounting reporting is significant (as $p=<0.05$ ). This is also shown by the mean difference, as the difference from the mean in case of SHREE Cement is minimum $(-0.17857)$ while is more in other companies and highest difference were found in Prism Cement company ($1.03571)$.

To identify the differences between the reporting of sustainable variables by selected cement companies, $\mathrm{t}$ test was again being used. This test will be useful to identify that the item-wise reporting of selected variables were similar among the different companies or not. The date collected for the above $t$ test was being used, which were divided into same 3 parts i.e., non-disclosed (1), non- 
Financial disclosure (2) and financial disclosure (3). The best way of reporting this sustainable information is to report for all the above items financially (3). As per the objectives one sample $\mathrm{T}$ test is being used for the data collected from the sample cement companies. The descriptive of the data were shown in Table-4.

Table 4

Descriptive Statistics of Item wise disclosure of sustainable reporting by Indian Cement Companies

\begin{tabular}{|c|c|c|c|c|c|c|c|c|}
\hline & \multirow{2}{*}{$\begin{array}{c}\mathrm{N} \\
\text { Statistic }\end{array}$} & \multirow{2}{*}{$\begin{array}{l}\text { Range } \\
\text { Statistic }\end{array}$} & \multirow{2}{*}{$\begin{array}{l}\text { Minimum } \\
\text { Statistic }\end{array}$} & \multirow{2}{*}{$\begin{array}{l}\text { Maximum } \\
\text { Statistic }\end{array}$} & \multicolumn{2}{|c|}{ Mean } & \multirow{2}{*}{$\begin{array}{l}\text { Std. Deviation } \\
\text { Statistic }\end{array}$} & \multirow{2}{*}{$\begin{array}{l}\text { Variance } \\
\text { Statistic }\end{array}$} \\
\hline & & & & & Statistic & Std. Error & & \\
\hline Energy & 10 & 1.00 & 2.00 & 3.00 & 2.8000 & .13333 & .42164 & .178 \\
\hline Water & 10 & 1.00 & 2.00 & 3.00 & 2.3000 & .15275 & .48305 & .233 \\
\hline Greenhouse Gases Emission & 10 & 2.00 & 1.00 & 3.00 & 2.1000 & .23333 & .73786 & .544 \\
\hline Hazardous and non-hazardous waste & 10 & 2.00 & 1.00 & 3.00 & 2.1000 & .23333 & .73786 & .544 \\
\hline Recycling & 10 & 2.00 & 1.00 & 3.00 & 1.9000 & .27689 & .87560 & .767 \\
\hline Agro based Livelihood & 10 & 2.00 & 1.00 & 3.00 & 1.7000 & .30000 & .94868 & .900 \\
\hline Mine de velopment & 10 & 2.00 & 1.00 & 3.00 & 2.2000 & .24944 & .78881 & .622 \\
\hline Waste Heat Recovery & 10 & 2.00 & 1.00 & 3.00 & 1.8000 & .24944 & .78881 & 622 \\
\hline Concrete Recycling & 10 & 2.00 & 1.00 & 3.00 & 1.4000 & .22111 & .69921 & .489 \\
\hline Packaging & 10 & 2.00 & 1.00 & 3.00 & 2.4000 & .22111 & .69921 & .489 \\
\hline Community investment & 10 & 1.00 & 2.00 & 3.00 & 2.5000 & .16667 & .52705 & .278 \\
\hline working condition & 10 & 2.00 & 1.00 & 3.00 & 2.3000 & .21344 & .67495 & 456 \\
\hline Human rights and fair trade & 10 & 2.00 & 1.00 & 3.00 & 2.3000 & .21344 & .67495 & .456 \\
\hline Public Policy & 10 & 1.00 & 2.00 & 3.00 & 2.3000 & .15275 & .48305 & 233 \\
\hline Diversity & 10 & 2.00 & 1.00 & 3.00 & 2.3000 & .21344 & .67495 & .456 \\
\hline Safety & 10 & 1.00 & 2.00 & 3.00 & 2.4000 & .16330 & .51640 & 267 \\
\hline Education & 10 & 2.00 & 1.00 & 3.00 & 2.0000 & .29814 & .94281 & .889 \\
\hline Health and family welfare & 10 & 1.00 & 2.00 & 3.00 & 2.5000 & 16667 & .52705 & 278 \\
\hline Anticorruption & 10 & 2.00 & 1.00 & 3.00 & 2.0000 & .25820 & .81650 & .667 \\
\hline Woman Empowerment & 10 & 2.00 & 1.00 & 3.00 & 1.4000 & .22111 & .69921 & .489 \\
\hline Self Help Groups SHG's & 10 & 2.00 & 1.00 & 3.00 & 1.5000 & .26874 & .84984 & .722 \\
\hline Accountability/Transparency & 10 & 1.00 & 2.00 & 3.00 & 2.8000 & .13333 & .42164 & 178 \\
\hline Corporate Governance & 10 & .00 & 3.00 & 3.00 & 3.0000 & .00000 & .00000 & .000 \\
\hline Stakeholder Value & 10 & .00 & 3.00 & 3.00 & 3.0000 & .00000 & .00000 & .000 \\
\hline Economic performance & 10 & .00 & 3.00 & 3.00 & 3.0000 & .00000 & .00000 & .000 \\
\hline Fuels and Material & 10 & 1.00 & 2.00 & 3.00 & 2.7000 & .15275 & .48305 & .233 \\
\hline Training & 10 & 2.00 & 1.00 & 3.00 & 2.3000 & .21344 & .67495 & .456 \\
\hline Financial Performance & 10 & .00 & 3.00 & 3.00 & 3.0000 & .00000 & .00000 & .000 \\
\hline Valid N (listwise) & 10 & & & & & & & \\
\hline
\end{tabular}

Table 4 shows that there is a significant difference between the item wise disclosures by the selected companies. Corporate Governance, Stakeholder Value, Economic performance and Financial Performance are among the variables in which no differences were observed as the standard deviation is 'zero', while in case of Agro based Livelihood the standard deviation is highest (0.94). T test were further calculated for calculating the mean difference, results of which were shown in Table 5.

Table 5

One-Sample Test of Item wise disclosure of sustainable reporting by Indian Cement Companies

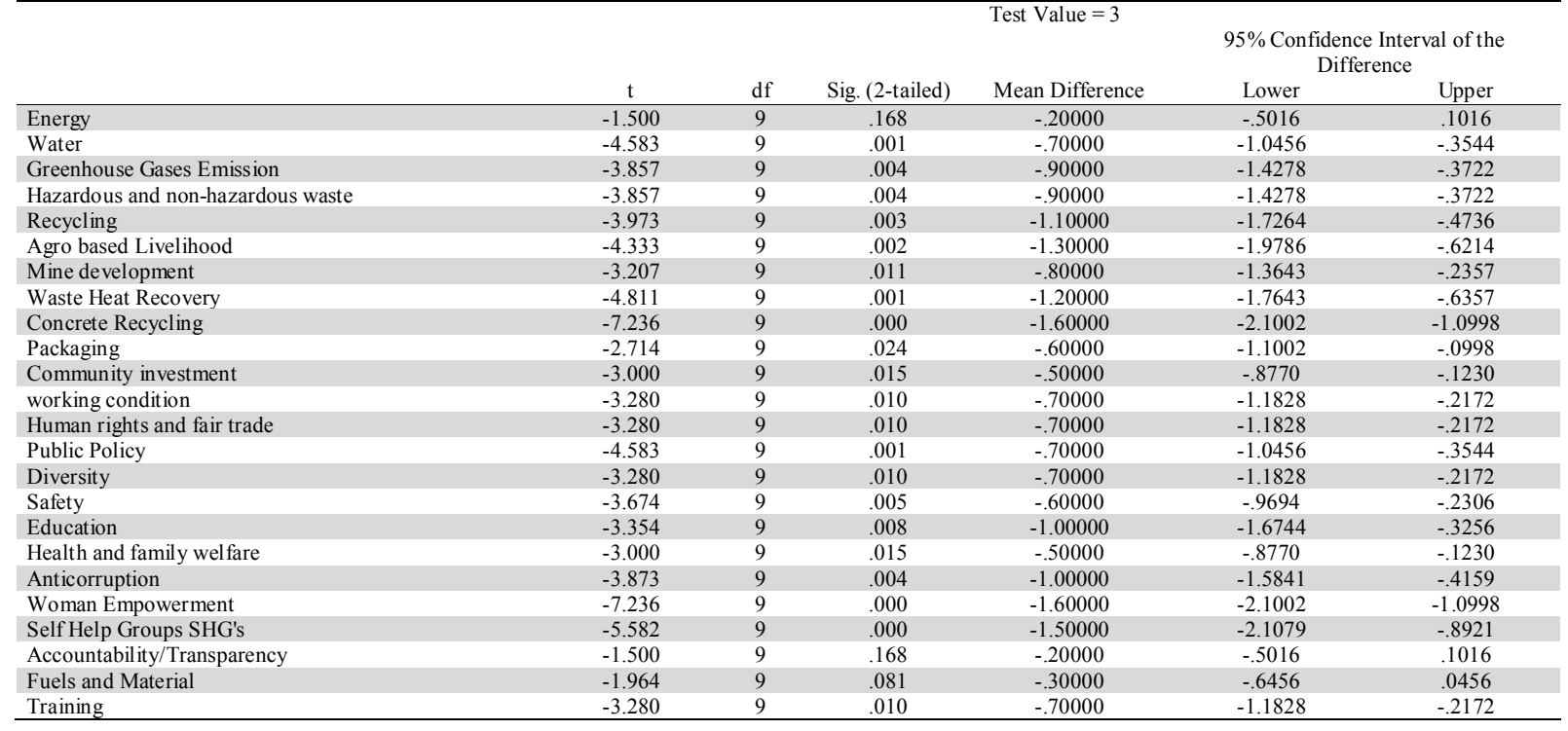


One sample Test of various sustainability factors shows that in only three factors were having a similar pattern of reporting i.e., Energy $(\mathrm{t}=-1.5, \mathrm{p}=0.168>0.05)$, Accountability/Transparency $(\mathrm{t}=-$ $1.500, p=.168>0.05)$ and Fuels and Material $(\mathrm{t}=-1.964$ and $\mathrm{p}=0.081>0.05)$, while on rest of the variables the difference in reporting of sustainable accounting reporting factors were significant (as $\mathrm{p}=<0.05)$.

\section{Conclusion}

Cement consumption is one of the major factors, which are behind the growth of the country, but manufacturing of cement is always creating carbon and other factors which damage the environment due to which these companies are called as environment hazardous companies. To convert these environmental hazardous companies sustainable, compulsory regulations are required in terms of disclosure under accounting and reporting related to sustainable issue in proper format i.e., in terms of financial character which effect and convert them into sustainable. Environmental Sustainable Accounting is helpful for these companies in this regards. The current study has unrevealed the fact that Sustainable Accounting reporting factors collected through reviews of literature which were examined under current study by taking sample of top 10 Indian cement companies results that except one company Shree Cement, uniform reporting pattern has not found. Not only that the reporting of the various sustainability variables were also found to be uncommon accept Energy efficiency, accountability, use of sustainable fuels and material. Hence, it can be finally concluded that unless there is a uniform accounting reporting system for sustainability practices, comparison between different companies will not be possible. Hence, it can be proposed that a framework of sustainable accounting reporting must be developed which provide a details of similar factors on which sustainable reporting should be done by in Indian Cement companies.

\section{References}

Adam, N. (2007). Corporate Environmental Reporting Expectation Gap: Evidence from India. The ICFAI Journal of Accounting Research, VI (2), 21-42.

Adams, C.A. (1998). Hill, W.Y. and Roberts, C.B., Corporate social reporting practices in Western Europe: Legitimating corporate behavior. British Accounting Review, 30, 1-21.

Adhikari, A., \& Tondkar, R. H. (1992). Environmental Factors Influencing Accounting Disclosure Requirements of Global Stock Exchanges. Journal of International Financial Management \& Accounting, 4, 75-105.

Ahmad, Z., Hassan, S., \& Mohhmad, J. (2003). Determinants of Environmental Reporting in Malaysia. International Journal of Business Studies, 11, 69-90.

Ali, W., \& Muhammad R. (2013). Factors Influencing Corporate Social And Environmental Disclosure (CSED) Practices In The Developing Countries: An Institutional Theoretical Perspective. International Journal of Asian Social Science, 3(3), 590-609

Andreson, M., \& Skjott -Larsen, T. (2009). Corporate social responsibility in global supply chains. Supply Chain Management, an International Journal, 14(2), 75-86.

Fung, A., Graham, M., \& Weil, D. (2001). The Political Economy of Transparency: What Makes Disclosure Policies Sustainable? Online from http://archonfung.net /docs/articles/2002/FGW Transparencyl.pdf.

Fernandez-Feijoo, B., Romero, S., \& Ruiz, S. (2013). Effect of Stakeholders' Pressure on Transparency of Sustainability Reports within the GRI Framework. Journal of Business Ethics, 111.

Bowman, E.H., \& Haire, M., A. (1975). Strategic Posture towards Corporate Social Responsibility. California Management Review, 18(2), 49-58.

Brown, N., \& Deegan, C. (1998). The public disclosure of environmental performance information a dual test of media agenda setting theory and legitimacy theory. Accounting and Business Research, 29(1), 21-41. 
Burritt, R.L., \& Welch, S. (1997). Australian commonwealth entities: An analysis of their environmental disclosures. ABACUS, 33(1), 69-87.

Chatterjee, B., \& Mir, M.Z. (2008). The current status of environmental reporting by Indian companies, Managerial Auditing Journal, 23(6), 609-629.

Chauhan, M., (2005). Concept of environmental accounting and practices in India. The Chartered Accountant, 54 (5), 720-726.

Cohen, J. R., Holder-Webb, L. L., Nath, L., \& Wood, D. (2012). Corporate reporting of nonfinancial leading indicators of economic performance and sustainability. Accounting Horizons, 26(1), 65-90.

Cormier, D., \& Magnan, M. (1997). Investor's assessment of implicit environmental liabilities: an empirical investigation. Journal of Accounting and Public Policy, 16, 215-241.

Cowen, S.S., Ferreri, L.B., \& Parker, L.D. (1987). The impact of corporate characteristics on social responsibility disclosure: A typology and frequency based analysis. Accounting Organization and Society, 12(2), 11-122.

Lorenz,D.P., Trück, S., \& Lützkendorf, T. (2007). Exploring the relationship between the sustainability of construction and market value: Theoretical basics and initial empirical results from the residential property sector. Property Management, 25(2),119-149

Fekrat, M.A., Inclan, C., \& Petroni, D. (1996). Corporate environmental disclosures: Competitive disclosure hypothesis using 1991 annual report data. The International Journal of Accounting, $31(2), 175-195$.

Fortes, A. (2002). The need for environmental reporting by companies. Green management International, 77-92.

Gamble G.O., Hsu, K., Kite, D., \& Radtke, R.R. (1995). Environmental disclosures in annual reports and 10Ks: An examination. Accounting Horizons, 9(3), 34-54.

Gray, R., Kouhy, R., \& Lavers, S. (1995). Corporate social and environmental reporting: a review of the literature and a longitudinal study of UK disclosure, Accounting. Auditing \& Accountability Journal, 8(2), 47-77.

Guthrie, J. and Parker, L.D. (1990). Corporate social disclosure practice: A comparative international analysis, Advances in Public Interest Accounting, 3, 159-175.

Hackston, D. and Milne, M.J. (1996). Some determinant of social and environmental disclosures in New Zealand companies. Accounting Auditing and Accountability Journal, 9(1), 77-108.

Hira, T. K. (2012), Promoting sustainable financial behaviour: implications for education and research. International Journal of Consumer Studies, 36, 502-507.

Ho, J.C.L., \& Taylor, M.E. (2007). An empirical analysis of triple bottom line reporting and its determinants: Evidence from the United States and Japan. Journal of International Financial Management and Accounting, 18, 123-150.

Idowu, S.O. (2011). Theory and practice of corporate social responsibility, Springer Heidelberg Dordrecht, London New York.

Kolk, A., Van der Veen, M. L., Van Wateringen, S. L., Van Der Veldt, D., \& Walhain, S. P. (1999). KPMG International survey of environmental reporting 1999.

Karl-Göran Mäler (1999). Resource accounting, sustainable development and well-being, resources accounting in China. Fondazione Eni Enrico Mattei (FEEM) Series on Economics, Energy and Environment, 12, 73-116

KPMG. (1997). International Survey of environmental Reporting, Stockholm: Copenhagen, May. Cited by Kolk, A. (1999). Evaluating corporate environmental reporting. Business Strategy and the Environment, 8(4), 225-237.

Laan, S.V.D. (2009). The role of theory in explaining motivation for corporate social disclosures: Voluntary disclosures vs 'Solicited' Disclosures. Australasian Accounting Business and Finance Journal, 3(4), 15-29.

Laurie, M. (2006). Integrating and reporting an organization's economic, social and environmental performance in expanded value added statement. Sustainability Accounting and Reporting, 21, 281-298. 
Lawrence, C.M., \& Khurana, I.K. (1997). Superfund liabilities and governmental reporting entities: An empirical analysis. Journal of Accounting and Public Policy, 16, 155-186.

Lorenz, D., Trück, S., \& Lützkendorf, T. (2007). Exploring the relationship between the sustainability of construction and market value - Theoretical basics and initial empirical results from the residential property sector. Property Management, 25(2), 119-149.

Lydenberg, S., \& Katie, G. (2008). Innovations in Social and Environmental Disclosure outside the United States. Domoni Social Investment, Report, 17-35.

Maria, S., Monterio, S., \& Guzman, B.A. (2010). Determinants of Environmental Disclosure in Annual Reports of large Companies Operating in Portugal. Corporate Social Responsibility and Environmental Management, 17(4), 185-204.

Michelon, G., \& Parbonetti, A. (2012). The effect of corporate governance on sustainability disclosure, Journal of Management \& Governance, 16(3), 477-509

Milne, MJ. (2010). Positive Accounting Theory, Political Costs and Social Disclosure Analyses: A Critical Look, Accountancy and Business Law. Dunedin, New Zealand: University of Otago.

Mitra, P.K. (2010). Sustainability Reporting Practices in India- Its Problems and Prospects. International Journal of Marketing, Financial Services \& Management Research, 1(5), 77-82.

Nash, J., \& Ehrenfeld, J. (1996). Code: Green Business Adopts Voluntary Environmental Standards, Environment, 38(1), 16-20.

Kuasirikun, N., \& Sherer, M. (2004). Corporate social accounting disclosure in Thailand. Accounting, Auditing \& Accountability Journal, 17(4), 629 - 660

Orij, R. P. (2012). Societal determinants of corporate social disclosures: an international comparative study, Doctoral thesis, Leiden University.

Pahuja, S. (2007). Corporate Environmental Reporting Expectation Gap: Evidence from India. The ICFAI Journal of Accounting Research, VI (2), 21-42.

Perego, P., Kolk, A.(2012). Multinationals' Accountability on Sustainability: The Evolution of Thirdparty Assurance of Sustainability Reports. Journal of Business Ethics, 110(2), 173-190

Perry, 2000, Green Reporting Grows Accountability Age, 15 Februrary, 2013, Cited from Holland, L., \& Boon Foo, Y. (2003). Differences in environmental reporting practices in the UK and the US: the legal and regulatory context. The British Accounting Review, 35(1), 1-18.

Pramanik, A.K., Shil, C.N., \& Das, B. (2007). Environmental accounting and reporting with special reference to India. $M P R A, 7712,1-25$.

Steurer, R., Langer, M.E., Konrad, A., \& Martinuzzi, A. (2013). Corporations, stakeholders and sustainable development I: A theoretical exploration of business-society relations. Journal of Business Ethics, 61(3), 263-281.

Reverte, C. (2009). Determinants of corporate social responsibility disclosure ratings by Spanish listed firms. Journal of Business Ethics, 88(2), 351-366.

Simnett, R., Vanstraelen, A., \& Chua, W.F. (2009). Assurance on sustainability reports: An international comparison. The Accounting Review, 84(3), 937-967.

Rüdiger, H, \& Regina, L. (2013). Legitimizing negative aspects in GRI-oriented sustainability reporting: A qualitative analysis of corporate disclosure strategies. Journal of Business Ethics, 115.

Samaha, K., \& Dahawy, K. (2010). Factors influencing corporate disclosure transparency in the active share trading firms: An explanatory study, in Mathew Tsamenyi, Shahzad Uddin (ed.) 10 (Research in Accounting in Emerging Economies, 10), Emerald Group Publishing Limited, 87-118

Samuel O. I. (2011). Accounting for decision makers in a sustainable environment, Theory and Practice of Corporate Social Responsibility, 209-228.

Schmidheiny, S. (1992). Changing Course a Global Business Perspective on Development and the Environment, Cambridge MA: MIT Press.

Sean Milmo. (2005). Chemical Market Reporter, freelance journalist, February 14.

Shankar, R., Agarwal, U., Goel, P., \& Jha, W. (2011). Business Strategies for the Indian Cement Industry, Manila, Philippines: IPEDR, IAC S IT Press 
Sharma, S., \& Ruud, A. (2003). On the path to sustainability: integrating social dimensions into the research and practice of environmental management. Business Strategy Environment, 12, 205-214.

Sing, R. I. (2007). Determinant of environmental disclosure- A study of Indian companies. The Accounting World, 56-66.

Smart, B. (1992). Beyond Compliance a New Industry view of the Environment, Washington, DC: World Resources Institute press.

Sulaiman A Al-T., Christensenb, T.E., \& Hughes, K.E. (2004).The relations among environmental disclosure, environmental performance, and economic performance: a simultaneous equations approach. Accounting, Organizations and Society. 29,447-471

Sumiani, Y., Haslinda, Y., \& Lehman, G. (2007). Environmental Reporting in a Developing Country: a Case Study on Status and Implementation in Malaysia. Journal of Cleaner Production, 15, 895901.

UNICD. (1992). The Rio Earth Summit: Summary of The United Nations Conference on Environment and Development, Stephanie Meakin, November, 1-10

Walden, W.D., \& Schwartz, B.N. (1997). Environmental disclosures and public policy pressure. Journal of Accounting and Public Policy, 16, 125-154.

Wiseman, J. (1982). An evaluation of environmental disclosures made in corporate annual reports. Original Research Article, Accounting, 7(1), 53-63

Williams, S.L.M. (1998). Voluntary environmental and social accounting disclosure practices in the Asia-Pacific region. $\mathrm{PhD}$ thesis, Murdoch University.

Wycherley, I. (1997). Environmental managers and accounting. Journal of Applied Management Studies, 6(2), 169-184. 